\title{
INFLUENCE OF SALVIA OFFICINALIS ESSENTIAL OIL ON DIGESTION PARAMETERS AND INTESTINAL MICROFLORA OF BROILER CHICKENS
}

\author{
Marcin, A. ${ }^{1}$, Levkut, M. ${ }^{1}$, Revajová, V. ${ }^{1}$, Šoltysová, B. ${ }^{2}$, Nad', P. ${ }^{1}$ \\ ${ }^{1}$ University of Veterinary Medicine and Pharmacy, Komenského 73, 04181 Košice \\ ${ }^{2}$ NAFC Nitra, Agroecology Research Institute, Špitálska 1273, 07101 Michalovce \\ The Slovak Republic \\ andrej.marcin@uvlf.sk
}

\section{ABSTRACT}

This study was aimed at the comparison of the effects of dietary applications of sage essential oil (Salvia officinalis $\mathrm{L}$.) on some digestive enzyme activities in the chyme of the jejunum, digestive characteristics, and selected bacterial microflora in the caecum. Seventy, one-day-old broiler chickens (Ross 308 ) were allocated into two equal groups for 42 days. The feed mixture of the experimental group was supplemented with the essential oil at the level of $2.306 \mathrm{~g} . \mathrm{kg}^{-1}$. This supplementation was absent in the control feed mixture. The main volatile compounds were analysed: Eucalyptol 85, alpha-thujon 148, betathujon 72, camphor 149 and borneol $37 \mathrm{~g} \cdot \mathrm{kg}^{-1}$. The digestive enzyme activities in the chyme of the jejunum increased as follows: amylolytic on days $16(\mathrm{P}<0.01)$ and $29(\mathrm{P}<0.001)$ as well as cellulolytic on days $16(\mathrm{P}<0.05)$, $29(\mathrm{P}<0.001)$, and $42(\mathrm{P}<0.01)$. The proteolytic activity decreased on day $16(\mathrm{P}<0.01)$. The intake of the additive, increased the digestibility of crude fibre $(\mathrm{P}<0.01)$ on days 16, 29 and 42. The apparent assimilable mass coefficient of crude protein, corrected for protein catabo- lism, was increased in the experimental group on days 29 $(\mathrm{P}<0.05)$ and $42(\mathrm{P}<0.01)$. The counts of Escherichia coli in the caecum decreased $(P<0.05)$ on days 29 and 42 . The supplementation of chickens with the sage essential oil increased the crude fibre digestibility, the amylolytic and cellulolytic activities in the chyme of the jejunum, and decreased the counts of $E$. coli in the caecum.

Key words: camphor; chickens; digestibility; essential oil; sage; thujone

\section{INTRODUCTION}

The search for new substances has been intensified since the ban of antibiotic performance enhancers in 2006 [26]. Therefore, an important group of effective and lowcost feed additives is no longer available.

One possible class of alternatives are plant extracts which are sources of different bioactive molecules with an effect on animal physiology and metabolism. Many of these compounds have been used in the form of whole plant ex- 
tracts for food or medicinal applications for human beings [35]. Phytoadditives, which are herbs or herbal derivates, have attracted attention in animal nutrition because of their potential role as alternatives to antibiotic growth promoters. Their efficacy in the nutrition of chickens depends on: composition, inclusion level of phytogenic preparations into feed, bird genetics, and composition of the diets [25].

These types of additives are containing various chemical compounds such as: saponins, essential oils, tannins, and flavonoids. These phytochemicals are isolated from medicinal, aromatic and spicy plants and possess potential values for the manipulation of poultry digestion and productivity.

Essential oils are very complex mixtures of volatile, lipophilic compounds originating from plants. Due to their lipophility, they possess good intestinal and percutaneous absorption properties. After oral intake, they stimulate the secretion of digestive enzymes and increase gastric and intestinal motility [36]. Essential oils are able of enhancing the production of digestive secretions, stimulating blood circulation, exerting antioxidant properties, reducing levels of pathogenic bacteria and may enhance the immune status [3].

The value of many research studies is quite limited. This is because the use of blends of phytogenic feed additives in their studies obscures the process of evaluating the individual effects of the separate essential oils utilized.

Whereas, numerous studies demonstrated the effects of sage extracts on the health status and blood chemistry of poultry in vivo $[7,11]$; there is a supposition that phytogenic compounds are able to enhance the enzyme activities and nutrient absorption in the digestive apparatus of poultry [37]. The effects of sage essential oil on the digestive characteristics, the enzyme activities in the small intestine, and selected intestinal microbial population are not entirely evident. Therefore, the objective of this study was to compare the influence of dietary intake of the sage essential oil on some digestive enzyme activities in the chyme of the jejunum, digestive characteristics and selected bacterial microflora in the caecum of broiler chickens.

\section{MATERIALS AND METHODS}

\section{Chickens and diets}

Seventy, one-day-old broiler chickens of hybrid Ross 308 , were delivered from a commercial hatchery. They were divided at random into 2 groups of 35 animals (control/ sage). The chickens were housed in two floor pens located in one hall of a chicken fattening farm (Michalovce, Slovak Republic) with constant access to feed and water. Both pens were identical with regard to the same direction and the same area $\left(0.12 \mathrm{~m}^{2}\right.$ per broiler chicken).

Both groups were fed with mash diets (domica Ltd., Slovak Republic) for 42 days (Table 1). The methionine was used as the first limiting amino acid. The diets were prepared and formulated without antibiotics and growth promoters. The anticoccidial agents were added into the starter and grower feed mixtures of both groups.

The essential oil was isolated from the tops of sage (Salvia officinalis L., family Lamiaceae) by steam distillation of the plant biomass in Calendula Inc. (Nová Lubovňa, Slovak Republic). The percentages of the main active compounds were analysed by gas chromatography (GC) using Hewlet-Packard 5890 Series II (injection input split splitless, capillary column HP-5, detector FIF, automatic injection HP 7673) with nitrogen as the carrier gas [10]. The herbal extract was added to diets of the experimental group with the resulting concentration of essential oils at the level of $2.306 \mathrm{~g} . \mathrm{kg}^{-1}$. The dosage of the sage essential oil, for the addition to the feed mixture, was selected according to previous results of chemical, microbiological and palatability tests [22]. The herbal ingredient was absent in the diets of the control group. The body weights of chickens were assessed once a week. The feed was weighed to evaluate the feed consumption.

\section{Feed analysis}

The samples of diets were analysed (Table 1) according to the official methods of the Association of Official Analytical Chemists [6]. The analyses were conducted for the determination of: dry mater (DM), crude protein (CP), crude fat (CF), ash, starch, and total carbohydrates. CF was analysed by the common method [34].

The ingredient composition of the experimental diets (g. $\mathrm{kg}^{-1}$ diet) (starter/grower/finisher) was as follows: wheat 150.0/160.0/150.0; maize 453.5/482.5/495.5; soybean meal 300.0/221.0/213.0; soya 30.0/59.0/57.0; sunflower meal 20.0/20.0/20.0; rape-seed oil 5.0/17.0/28.0; calcium carbonate 13.0/14.5/14.0; sodium chloride 4.0/4.0/4.0; calcium hydrophosphate 13.5/10.5/10.5; L-Lysine 4.0/5.0/2.5; DL - Methionine 2.0/1.5/0.5; and Vitamin-mineral premix 5.0/5.0/ 5.0. Anticoccidial agent in diets: starter - Robenidin, grower - Narasin, and finisher - absent. 
Table 1. Chemical composition of the experimental diets ( $\left.\mathbf{g} \cdot \mathrm{kg}^{-1} \mathrm{diet}\right)$

\begin{tabular}{lccc}
\hline \multicolumn{1}{c}{ Ingredients } & Experimental diets & Finisher \\
\hline Dry mater & Starter & Grower & 898.04 \\
Crude protein & 881.90 & 890.27 & 214.40 \\
Crude fat & 248.20 & 223.10 & 46.30 \\
Crude fibre & 26.15 & 38.62 & 31.30 \\
Crude ash & 44.10 & 35.20 & 55.30 \\
Starch & 66.00 & 57.90 & 416.55 \\
Total carbohydrates & 340.34 & 398.02 & 52.20 \\
Calcium & 42.92 & 59.85 & 9.19 \\
Phosphorus & 9.68 & 9.41 & 7.21 \\
Sodium & 7.59 & 7.38 & 1.41 \\
Methionine & 1.82 & 1.80 & 4.23 \\
Lysine & 3.92 & 4.56 & $12.71 \mathrm{MJ}$ \\
Cystine & 10.05 & 13.39 & 2.05 \\
Metabolizable energy* & 2.98 & $12.42 \mathrm{MJ}$ & \\
\hline
\end{tabular}

* Calculation based on Kirchgesner and Roth [18]

Mineral content (mg.kg-1 diet): $\mathrm{Mg} \mathrm{100.0,} \mathrm{Mn} \mathrm{80.0,}$ Zn 60.0, Fe 60.0, Cu 5.0, Co 0.2, J 1.0, and Se 0.15. Vitamin content (mg. $\mathrm{kg}^{-1}$ diet): retinol (A) 2.4, cholecalciferol (D3) 30.0, tocopherol (E) 20.0, menadione (K3) 4.0, thiamine (B1) 6.0, riboflavin (B2) 3.0, pyridoxine (B6) 5.0, cobalamin (B12) 0.02, folic acid (B9) 1.0, D-biotin (B7) 0.05, calcium D-panthothenate (B5) 10.0, and niacin (B3) 25.0.

The amino acid analyses of the experimental diet were performed by high performance liquid chromatography with AAA 400 amino acid analyser (INGOS, Czech Republic). This analyser is designed for the determination of amino acids on an ion exchanger column with a post-column derivatisation by means of ninhydrin. Lysine was determined after hydrolysis for $24 \mathrm{~h}$ at $110^{\circ} \mathrm{C}$ with $6 \mathrm{~mol} . \mathrm{l}^{-1} \mathrm{HCl}$. Sulphur-containing amino acids, methionine and cystine were analysed after cold formic oxidation for $16 \mathrm{~h}$ before the acid hydrolysis. The mineral composition of the feed $(\mathrm{Ca}, \mathrm{Na})$ was determined by atomic absorption spectro- photometry (AAS) with Shimadzu AA 6200 after the feed sample ashing in a muffle furnace [33]. The quantitative determination of phosphorus was performed spectrophotometrically [5]. The insoluble portion of ash in $\mathrm{HCl}$ was determined in the feed mixture as the residue of ash, after dissolving ash in diluted hydrochloric acid by weighing [8].

\section{Blood analysis}

Ten broilers from each group were randomly selected and anaesthetized with intraperitoneal injections of xylazine 0.6 ml. $\mathrm{kg}^{-1}$ (Rometar $2 \%$, SPOFA, Czech Republic) and ketamine $0.7 \mathrm{ml} . \mathrm{kg}^{-1}$ body weight (Narkamon $5 \%$, SPOFA, Czech Republic) on 16, 29 and 42 days of age. The numbers of birds were 25, 15 and 5 in the groups on days 16, 29 and 42 after selection. Blood samples for the preparation of the sera were taken by intracardial puncture after laparotomy and applied into anticoagulant-free tubes. The separation of sera was performed by centrifugation and the samples 
were kept at $20^{\circ} \mathrm{C}$ until examination. The determination of the total protein concentration in the serum was performed by the Bradford method at a wavelength of $595 \mathrm{~nm}$ [2]. The contents of calcium, magnesium and potassium were determined by AAS [33]. The quantitative determination of phosphorus was performed spectrophotometrically [5].

\section{Analysis of intestinal contents}

The samples of chyme from the jejunum and the caecum were placed into sterile tubes for digestive enzyme analyses and microbiological assays immediately after necropsy. The preparation of samples for the quantification of digestion enzymes activities was performed as follows. One gram of fresh sample was diluted with $49 \mathrm{ml}$ sterile TBS buffer (TRIS-hydroxymethyl aminomethane $10 \mathrm{mmol}^{-1}{ }^{-1}, \mathrm{HCl}$ 0.5 mol. $1^{-1}, \mathrm{pH} 7.0$ ) and homogenised. The samples were subsequently taken for the measurement of nonspecific proteolytic activity [4] with the substrate azocasein (Merck Ltd., Germany). The cellulolytic and the amylolytic activity [21] were analysed with the substrates methylhydroxyethylcellulose (Merck Ltd., Germany) and starch (Fisher Slovakia Ltd.), respectively. The quantification of the protein concentration was performed by the Bradford method [2].

For the microbiological examination, the caecal digesta were diluted 10 fold $(1: 9 \mathrm{w} / \mathrm{v})$ by blending them with the anaerobically sterilized TBS buffer. Thereafter, a $0.1 \mathrm{ml}$ sample was diluted by 10-2-10-7 and spread onto sterilized selective nutrient media McConkey agar (Merck Ltd., Germany) for Escherichia coli; Slanetz-Bartley agar (Merck Ltd., Germany) for Enterococcus spp.; and Rogosa agar (Merck Ltd., Germany) for Lactobacillus spp. for the purpose of cultivation. The numbers of Colony Forming Units (CFU.g ${ }^{-1}$ ) of wet caecal digesta of E. coli and Enterococcus spp., were optically enumerated after aerobic cultivation for $24 \mathrm{~h}$, whereas Lactobacillus spp. after stationary anaerobical cultivation for $48 \mathrm{~h}$ at $37^{\circ} \mathrm{C}$.

\section{Check of digestibility}

The digestibility was checked on 16, 29 and 42 days of age. The excreta was sampled directly from the cloaca into sterile glass containers on the designated day. The quantifications of crude fibre, ash and portion of insoluble ash in $\mathrm{HCl}$ were performed in excreta according to methods of D a něk et al. [8].
The digestibility coefficient (dc) was calculated according to the formula:

$100-\frac{\text { sample of excreta/ash insoluble in } \mathrm{HCl} \text { in excreta }}{\text { sample of feed mixture/ash insoluble in } \mathrm{HCl} \text { in feed mixture }}$

The digestibility was determined by calculating the analysed content of nutrients in feed and excreta concerning the content of the insoluble portion of ash. The digestibility measurement of crude protein of broiler chickens with the correction for uric acid nitrogen was performed as follows: the contents of crude protein were measured in the excreta by Kjeldahl method [19] with the instrument Foss 2300 Kjeltec analyser (Foss Tecator, Sweden).

Because a part of the crude protein in the excreta originates from uric acid, the faecal crude protein should be corrected for uric acid nitrogen. At first, the correction for the endogenous losses resulting from protein catabolism was performed by determining the crude protein balance $(\mathrm{Nb})$ of the animal as follows:

$$
\mathrm{Nb}=\mathrm{QiNi}-\mathrm{QeNe}
$$

where Ni represents the crude protein content $\left(\mathrm{g}_{\mathrm{kg}} \mathrm{kg}^{-1}\right)$ of the feed, and Ne the crude protein content $\left(\mathrm{g}_{\mathrm{kg}} \mathrm{kg}^{-1}\right)$ of the excreta, Qi and Qe are the rates of feed intake and excretal output $\left(\mathrm{g} \cdot \mathrm{kg}^{-1} \cdot \mathrm{day}^{-1}\right)$. Subsequently, the crude protein losses to the moles of uric acid were converted to calculate the mass losses associated with uric acid excretion [29]. The mass correction for uric acid nitrogen is $3 \mathrm{~g}^{-\mathrm{g}^{-1}} \mathrm{~N}$ [17]. Given these values, the equation for the apparent assimilable mass coefficient of crude protein corrected for protein catabolism (AMCN) was as follows:

$$
\mathrm{AMCN}=1-([\mathrm{Qe}+3(\mathrm{Nb})] / \mathrm{Qi})
$$

\section{Statistical analysis}

The data are expressed as means \pm standard deviation (SD) of single values (SAS, Version 8.2; SAS Institute Inc., 1999, Cary, NC USA). Means of the results from the treatments were compared by one-way analysis of variance. Treatment means were statistically compared by TukeyKramer multiple comparison test. Significance was declared at $\mathrm{P}<0.05, \mathrm{P}<0.01$, and $\mathrm{P}<0.001$. 


\section{RESULTS}

The percentage ranges of the active compounds of the sage essential oil are reported in Table 2. Digestive enzyme activities (amylolytic, cellulolytic, proteolytic) were assessed in the chyme of the jejunum (Table 3 ). The intake of the sage essential oil added into the feed mixture caused, on the one hand, enhancement of amylolytic activity on days $16(\mathrm{P}<0.01)$ and $29(\mathrm{P}<0.001)$, and on the other hand, a decrease on day $42(\mathrm{P}<0.05)$. The cellulolytic activity was increased on days $16(\mathrm{P}<0.05), 29(\mathrm{P}<0.001)$ and $42(\mathrm{P}<0.01)$. The decrease of the proteolytic activity was observed in the experimental group on day $16(\mathrm{P}<0.01)$. The digestibility data of crude fibre and ash, as well as, the

Table 2. Gas chromatography analysis of active volatile compounds of the sage essential oil

\begin{tabular}{ccc}
\hline Plant source & Compound & $\begin{array}{c}\text { Content } \\
{\left[\mathrm{g} \cdot \mathrm{kg}^{-1}\right]}\end{array}$ \\
\hline Eucalyptol & $85 \pm 1$ \\
Sage* & Beta-thujon & $148 \pm 1$ \\
& Camphor & $72 \pm 1$ \\
& Borneol & $149 \pm 1$ \\
\hline
\end{tabular}

* — the analysed density of sage essential oil was $0.915 \pm 0.001 \mathrm{~g} \cdot \mathrm{cm}^{-3}$ apparent assimilable mass coefficient of crude protein corrected for protein catabolism are summarized in Table 4.

The comparison of digestibility coefficients demonstrated a better utilisation of the experimental feed mixture, as far as the digestibility of crude fibre is concerned. The values of this parameter were increased on days $16(\mathrm{P}<0.01)$, $29(\mathrm{P}<0.01)$ and $42(\mathrm{P}<0.01)$. The AMCN value increased in the experimental group on days $29(\mathrm{P}<0.05)$ and 42 $(\mathrm{P}<0.01)$. The changes of total protein and macroelements (phosphorus, potassium, calcium, magnesium) in the serum are shown in Table 5. The level of serum total protein was significantly higher $(\mathrm{P}<0.05)$ in the experimental group on day 29. The microbiological counts in the caecal chyme of broiler chickens are summarized in Table 6. The total counts of $E$. coli were significantly lower $(\mathrm{P}<0.05)$ in the experimental group on days 29 and 42 . The basic growth data and the average feed intake of broiler chickens on days 16, 29 and 42 are summarized in Table 7 . There was observed a significantly higher body weight $(\mathrm{P}<0.05)$ in the experimental group in comparison to control on day 42 .

\section{DISCUSSION}

As far as the chemical composition of the sage essential oil is concerned, it is divided into ketones (camphore, $\alpha, \beta$-thujone), terpenes (limonene, $\alpha, \beta$-pinene) and alcohols (borneol, linalool) [12]. The sage essential oil tested in our study contained the following active com-

Table 3. Digestive enzyme activities in the chyme of the jejunum of broiler chickens $(n=16 ;$ mean \pm SD)

\begin{tabular}{|c|c|c|c|c|}
\hline $\begin{array}{l}\text { Age } \\
{[\text { day] }}\end{array}$ & Group & 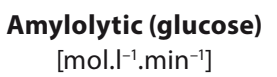 & $\begin{array}{l}\text { Cellulolytic activity (glucose) } \\
\qquad\left[\mathrm{mol}^{\left.-\mathrm{I}^{-1} \cdot \mathrm{min}^{-1}\right]}\right.\end{array}$ & $\begin{array}{c}\text { Proteolytic activity (azocasein) } \\
\qquad\left[\mathrm{g} \cdot \mathrm{ml}^{-1} \cdot \mathrm{min}^{-1}\right]\end{array}$ \\
\hline \multirow{2}{*}{16} & Control & $0.17^{\mathrm{a}} \pm 0.011$ & $0.11^{\mathrm{a}} \pm 0.025$ & $0.77^{\mathrm{a}} \pm 0.063$ \\
\hline & Sage & $0.26^{c} \pm 0.038$ & $0.13^{b} \pm 0.023$ & $0.48^{c} \pm 0.062$ \\
\hline \multirow{2}{*}{29} & Control & $0.10^{\mathrm{a}} \pm 0.013$ & $0.07^{a} \pm 0.015$ & $0.41^{\mathrm{a}} \pm 0.048$ \\
\hline & Sage & $0.15^{d} \pm 0.032$ & $0.13^{d} \pm 0.038$ & $0.41^{\mathrm{a}} \pm 0.035$ \\
\hline \multirow{2}{*}{42} & Control & $0.14^{\mathrm{a}} \pm 0.017$ & $0.16^{\mathrm{a}} \pm 0.026$ & $0.60^{\mathrm{a}} \pm 0.066$ \\
\hline & & $012 b+0015$ & $023+0$ & $055 a$ \\
\hline
\end{tabular}


Table 4. Apparent assimilable mass coefficient of crude protein and digestibility of crude fibre and ash $(\mathrm{n}=8$; mean $\pm \mathrm{SD})$

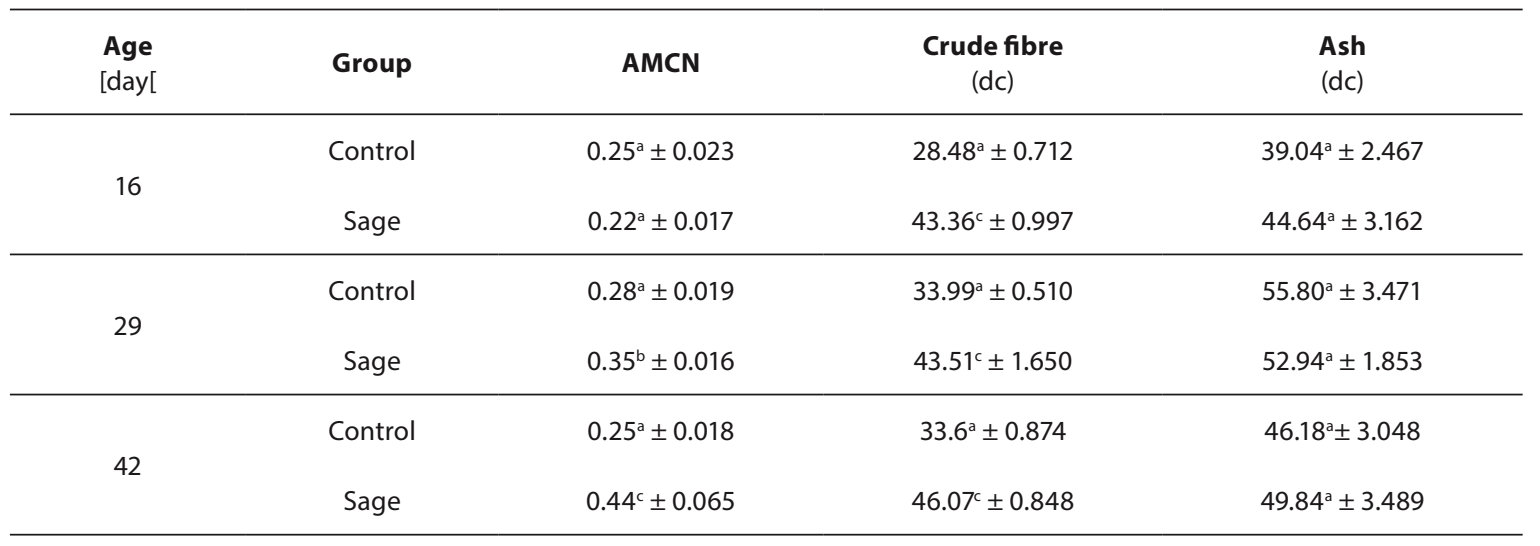

AMCN — apparent assimilable mass coefficient of crude protein corrected for protein catabolism; dc — digestibility coefficient means with different superscript letters differ significantly: ${ }^{a, b}-P<0.05 ;^{a, c}-P<0.01 ;^{a, d}-P<0.001$

Table 5. Biochemical parameters in the serum of broiler chickens ( $\mathrm{n}=8$, mean $\pm S D$ )

\begin{tabular}{|c|c|c|c|c|c|c|}
\hline $\begin{array}{l}\text { Age } \\
{[\text { day] }}\end{array}$ & Group & $\begin{array}{c}\text { Total protein } \\
{\left[\mathrm{g} . \mathrm{l}^{-1}\right]}\end{array}$ & $\begin{array}{c}\mathbf{P} \\
{\left[\mathrm{mg} \cdot \mathrm{dl}^{-1}\right]}\end{array}$ & $\begin{array}{c}\mathbf{K} \\
{\left[\mathrm{mg} \cdot \mathrm{dl}^{-1}\right]}\end{array}$ & $\begin{array}{c}\text { Ca } \\
{\left[\mathrm{mg} \cdot \mathrm{dl}^{-1}\right]}\end{array}$ & $\begin{array}{c}\text { Mg } \\
{\left[\mathrm{mg}^{\left.-\mathrm{dl}^{-1}\right]}\right.}\end{array}$ \\
\hline \multirow{2}{*}{16} & Control & $154.85^{\mathrm{a}} \pm 4.94$ & n.d. & n.d. & n.d. & n.d. \\
\hline & Sage & $153.99^{\mathrm{a}} \pm 2.80$ & n.d. & n.d. & n.d. & n.d. \\
\hline \multirow{2}{*}{29} & Control & $115.08^{a} \pm 5.65$ & $15.41^{\mathrm{a}} \pm 2.98$ & $19.07^{\mathrm{a}} \pm 1.4$ & $11.70^{\mathrm{a}} \pm 3.33$ & $3.09^{a} \pm 0.44$ \\
\hline & Sage & $120.64^{b} \pm 5.19$ & $13.70^{\mathrm{a}} \pm 1.96$ & $20.27^{\mathrm{a}} \pm 2.85$ & $11.28^{\mathrm{a}} \pm 2.39$ & $3.03^{a} \pm 0.45$ \\
\hline \multirow{2}{*}{42} & Control & $176.88^{a} \pm 12.18$ & $14.54^{\mathrm{a}} \pm 2.74$ & $20.32^{\mathrm{a}} \pm 2.72$ & $9.03^{a} \pm 2.52$ & $2.68^{\mathrm{a}} \pm 0.48$ \\
\hline & Sage & $181.14^{a} \pm 7.16$ & $12.91^{\mathrm{a}} \pm 1.83$ & $20.27^{a} \pm 2.56$ & $12.01^{\mathrm{a}} \pm 3.51$ & $3.11^{\mathrm{a}} \pm 0.68$ \\
\hline
\end{tabular}

n.d. - not determined; means with different superscript letters differ significantly: ${ }^{a, b}-P<0.05$

pounds: eucalyptol (1,3,3-trimethyl-2-oxabicyclo[2,2,2] octane), $\alpha$-thujone (1S,4R,5R)-4-methyl-1-(propan-2-yl) bicyclo[3.1.0] hexan-3-one, $\beta$-thujone (1S,4S,5R)-4-methyl-1-propan-2-ylbicyclo[3.1.0]hexan-3-one, camphor (1,7,7-trimethylbicyclo[2.2.1]heptan-2-one) and borneol (endo-1,7,7-timethyl-bicyclo[2.2.1]heptan-2-ol). In addition to these compounds, the essential oil, if an extract equivalent to $14.9 \%$ of dry sage is used, contains: $6.9 \%$ rosmarinic acid (55\% recovery), 10.6\% carnosic compounds (75\% recovery) and $7.3 \%$ essential oil (42\% recovery) [9]. According to the cluster analysis [20], the leaf age and origin of the plants, has a significant impact on the composition of the essential oils. Additionally, Zheljazkov et al.
[38] evaluated the effect of distillation times on sage essential oil yields and its composition. They concluded that the duration of the extraction process with the steam distillation has the potential to change the chemical composition of the produced essential oil.

Our study demonstrated that the dietary addition of essential oil from sage can be substantial for avian and herbivores in various aspects.

The significant increase of amylolytic and cellulolytic activity, as well as the decrease of proteolytic activity were observed in the jejunum in some sampling periods.

According to Rideau et al. [27] it is proposed that the modification of the chyme and transit rates during the day 
Table 6. Microbial counts in the caecal chyme of broiler chickens

$\left(n=6 ; \log C F U . g^{-1}\right.$ wet digesta)

\begin{tabular}{|c|c|c|c|c|}
\hline $\begin{array}{l}\text { Age } \\
\text { [day] }\end{array}$ & Group & Lactobacillus spp. & Enterococcus spp. & E. coli \\
\hline \multirow{3}{*}{16} & Control & $8.0^{\mathrm{a}}$ & $5.60^{\mathrm{a}}$ & $7.04^{\mathrm{a}}$ \\
\hline & & & & \\
\hline & Sage & $8.18^{a}$ & $6.36^{a}$ & $6.85^{\mathrm{a}}$ \\
\hline \multirow{3}{*}{29} & Control & $8.32^{\mathrm{a}}$ & $6.20^{\mathrm{a}}$ & $7.15^{\mathrm{a}}$ \\
\hline & & & & \\
\hline & Sage & $8.64^{a}$ & $6.60^{a}$ & $6.11^{\mathrm{b}}$ \\
\hline \multirow{3}{*}{42} & Control & $8.48^{a}$ & $6.89^{a}$ & $7.30^{\mathrm{a}}$ \\
\hline & & & & \\
\hline & Sage & $8.94^{\mathrm{a}}$ & $7.08^{a}$ & $6.69^{b}$ \\
\hline
\end{tabular}

Means with different superscript letters differ significantly ${ }^{\mathrm{a}, \mathrm{b}}-\mathrm{P}<0.05$; CFU - colony forming units

Table 7. Basic growth data and feed intake of broiler chickens in the experiment $($ mean \pm SD)

\begin{tabular}{|c|c|c|c|c|c|c|c|}
\hline \multirow{2}{*}{ Group } & \multirow{2}{*}{$\begin{array}{c}\text { IBW } \\
{[\mathrm{g}]}\end{array}$} & \multicolumn{3}{|c|}{$\begin{array}{l}\text { BW } \\
{[\mathrm{g}]}\end{array}$} & \multicolumn{3}{|c|}{$\begin{array}{c}\text { ADFI } \\
{\left[\text { g.day }{ }^{-1}\right]}\end{array}$} \\
\hline & & $\begin{array}{l}\text { day } 16 \\
(n=35)\end{array}$ & $\begin{array}{l}\text { day } 29 \\
(n=25)\end{array}$ & $\begin{array}{l}\text { day } 42 \\
(n=15)\end{array}$ & $\begin{array}{c}\text { day } 1-16 \\
(n=35)\end{array}$ & $\begin{array}{c}\text { day } 17-29 \\
(n=25)\end{array}$ & $\begin{array}{c}\text { day } 30-42 \\
(n=15)\end{array}$ \\
\hline Control & $38.86^{\mathrm{a}} \pm 6.71$ & $257.11^{\mathrm{a}} \pm 53.66$ & $773.29^{a} \pm 237.62$ & $1746.67^{a} \pm 340.52$ & $29.39^{a} \pm 6.33$ & $80.45^{a} \pm 28.67$ & $160.63^{\mathrm{a}} \pm 41.58$ \\
\hline Sage & $40.57^{a} \pm 4.75$ & $257.92^{\mathrm{a}} \pm 53.35$ & $886.38^{a} \pm 259.29$ & $1947.06^{b} \pm 274.14$ & $28.69^{\mathrm{a}} \pm 6.42$ & $89.52^{\mathrm{a}} \pm 29.33$ & $203.30^{a} \pm 26.87$ \\
\hline
\end{tabular}

Means with different superscript letters differ significantly ${ }^{a, b}-P<0.05$; CFU - colony forming units; IBW — initial body weight; BW — body weight; ADFI — average daily feed intake

may affect the pancreatic enzyme fate and distribution in the small intestine as well as they observed that intestinal contents and enzyme activities were higher in egg-forming than in non-egg-forming laying hens. B a s m a ci oglu et al. [1] determined the effect of dietary supplementation of oregano essential oil on the digestive enzymes and nutrient digestibility of broilers fed wheat-soybean meal based diets. The dietary supplementation of essential oil at two levels (250 and $500 \mathrm{mg} \cdot \mathrm{kg}^{-1}$ ) with or without enzyme, significantly increased the activity in the digestive system and improved crude protein digestibility.

Positive effects of the sage essential oil on the digestibility of the crude fibre in the sampling periods were observed, which is a positive relation with regard to the increased values of cellulolytic activity. Gugliem o and Karas ov [14] calculated that the utilization of feed in birds is influenced by the mixing of urinary wastes with the undigested feed passing through the cloaca. Similarly, continual loss of mass and energy from the gastrointestinal tract in the form of epithelial cells, microbes and digestive secretions was observed. In cases where the endogenous losses of mass have not been quantified, the apparent assimilable mass coefficient (AMC) can be calculated as follows:

$$
\mathrm{AMC}=(\mathrm{Qi}-\mathrm{Qe}) / \mathrm{Qi}=1-\mathrm{Qe} / \mathrm{Qi}
$$


Hernández et al. [15] demonstrated that plant extract supplementation of diets for broiler chickens for 42 days improved apparently the whole-tract and ileal digestibility of the nutrients. The improvement of apparent faecal digestibility of DM and the ether extract digestibility were significant after dietary intake of 5,000 ppm essential oil extract from sage, thyme and rosemary in starter feed but no effect was detected for CP digestibility. Whereas, the extracts caused an improvement of the apparent faecal digestibility of DM and CP of the finisher diet.

The positive increase of total protein level in serum after intake of the sage essential oil was observed on day 29 in the experimental broiler chickens.

On the contrary, Traesel et al. [31], evaluated serum proteins with electrophoresis and plasma lipid peroxidation in broilers fed with diets supplemented with antibiotics or the blend of essential oils from oregano (Origanum vulgare L.), sage (Salvia officinalis L.), rosemary (Rosmarinus officinalis L.) and pepper (Capsicum frutescens L.) crude extracts. The total globulins and betaglobulin fraction significantly decreased in the experimental groups after supplementation of the diet with $150 \mathrm{mg} \cdot \mathrm{kg}^{-1}$ essential oils after 42 days of the experiment. However, the values of: albumin fractions, globulins ( $\alpha-1, \alpha-2, \gamma$-glob), and the albumin/globulin ratio did not change significantly.

Therefore, the decrease in total globulins was due to a decrease in the betaglobulins. The decreased concentrations of betaglobulins or gamma globulins in the absence of hypoalbuminemia usually result from the decreased concentration of immunoglobulins which is the result of the effect of the blend of essential oils.

In addition to the dietary dosage of essential oils, the reason of the lower dosage of the blend of plant extracts with the carvacrol as the major component, into the diet, was the utilization of the microencapsulation technique, due to the volatility of essential oils [31]. Whereas, the sage essential oil was applied unprotected into feed mixture after dilution in the plant oil in the experiment.

The sage essential oil does not influenced the levels of macroelements in the sera of experimental animals after dietary intake. According to Ča pkovičová et al. [7], the addition of sage extract $(0.05$ and $0.1 \%)$ to the diet, led to a decreased concentration of plasma calcium (Ca reference values $\left.2.09-2.52 \mathrm{mmol.} \mathrm{l}^{-1}\right)$; whereas, the levels of plasma phosphorus and magnesium did not differ significantly between treatments (phosphorus, magnesium reference values $1.60-2.10$ and $0.75-1.3 \mathrm{mmol}^{-\mathrm{l}^{-1}}$, resp.). Similarly, Faixová et al. [11] observed that feeding chickens with diets supplemented with sage essential oil had a reducing effect on plasma calcium levels and demonstrated a reducing effect of borneol on plasma level of the element.

The in vivo experiment demonstrated a significant decrease of the E. coli population in the caecal chyme of broiler chickens after the intake of the sage essential oil as a result of our observations. Gut mucus and produced mucin could have influence on antibacterial protection of the gastrointestinal apparatus of broiler chickens against $E$. coli.

According to the published experimental results dealing with the antimicrobial activity of essential oils, the sage essential oil is typical with the lower activity in comparison with the similar extracts from oregano, thyme, clove and cinnamon. This declaration is in compliance with the results of S a n turio et al. [28] who evaluated the antimicrobial activities of essential oils from Origanum vulgare (oregano), Thymus vulgaris (thyme), Lippia graveolens (Mexican oregano), Cinnamomum zeylanicum (cinnamon), Zingiber officinale (ginger), Salvia officinalis (sage), Rosmarinus officinalis (rosemary) and Ocimum basilicum (basil) against Escherichia coli strains isolated from poultry $(\mathrm{n}=43)$ and cattle faeces $(n=36)$. They observed the highest antimicrobial activity of the essential oils from oregano, Mexican oregano, thymus and cinnamon. Further, Ša rić et al. [30] determined the chemical composition and antimicrobial properties of Salvia officinalis with the main components of essential oil: $28.64 \%$ of camphor, $21.90 \%$ of 1,8 cineole and $19.92 \%$ of $a$-thujone (16.92\%). The essential oil showed antimicrobial activity against all bacteria tested in the MIC range of $0.16-5.00 \mathrm{mg}^{-\mathrm{ml}^{-1}}$ and $\mathrm{MBC}$ range of $0.63-5.00$ mg. $\mathrm{ml}^{-1}$. Similarly, Mekinić et al. [23] tested the contents of phenolics and antibacterial activity of five Lamiaceae plant extracts (sage, thyme, lemon balm, peppermint and oregano) against major foodborne pathogens such as Campylobacter coli, Escherichia coli, Salmonella Infantis, Bacillus cereus, Listeria monocytogenes and Staphylococcus aureus. They determined the highest content of total phenolics and non-flavonoids was in the sage extract, and it showed the best antibacterial activity, especially against Gram-positive bacteria and E. coli. However, the data presented by Golestani et al. [13] indicated that the potential antibacterial activity of the essential oil remedies (Thymus vulgaris, Allium cepa, Allium sativum, Eucalyptus globulus, Salvia officinalis, Dianthus caryophyllus, Mentha spicata and Men- 
tha piperita) against Escherichia coli O157:H7 by the disk diffusion method, could be suitable against colibacillosis, although this claim has to be confirmed in experimental and clinical trials.

The sage essential oil is able to influence the body weight, but not the average daily feed intake. Similar results were obtained by Traesel et al. [32] who evaluated the performance data in broilers fed diets supplemented with antibiotics or essential oils from oregano, sage, rosemary, and pepper crude extract. The dose of essential oils at the level of $100 \mathrm{mg} \cdot \mathrm{kg}^{-1}$ is suitable for a final body weight and a weight gain similar to those which were observed in broilers supplemented with antibiotic growth promoters. Furthermore, Hernán dez et al. [15] did not observe any difference in feed intake or feed conversion after a dietary intake of 5,000 ppm essential oil extract from Labiatae plants (sage, thyme, rosemary) in broilers in the feeding period of 42 days. However, the growth of birds was faster in the controls.

\section{CONCLUSIONS}

The supplementation of diets for broiler chickens with the sage essential oil beneficially increased the amylolytic and cellulolytic activities in the chyme of the jejunum, the digestibility of crude fibre and caused a decrease of CFU of E. coli in the content of the caecum.

\section{ACKNOWLEDGEMENTS}

This study was supported by a grant from the Slovak Research and Development Agency (SRDA) APVV-20-041605 and the project of the Ministry of Education KEGA-009UV$L F-4 / 2015$.

\section{REFERENCES}

1. Basmacioğlu Malayoğlu, H., Baysal, S., Misirlioğlu, Z., Polat, M., Yilmaz, H., Turan, N., 2010: Effects of oregano essential oil with or without feed enzymes on growth performance, digestive enzyme, nutrient digestibility, lipid metabolism and immune response of broiler fed on wheat-soybean meal diets. Br. Poult. Sci., 51, 67-80.
2. Bradford, M. M., 1976: A rapid and sensitive method for the quantitation of microgram quantities of protein utilizing the principle of protein-dye binding. Anal. Biochem., 72, 248-254.

3. Brenes, A., Roura, E., 2010: Essential oils in poultry nutrition: Main effects and modes of action. Animal Feed Science and Technology Biochem., 158, 1-14.

4. Broderick, G.A., 1987: Determination of protein degradation rates using a rumen in vitro system containing inhibitors of microbial nitrogen metabolism. Br. J. Nutr., 58, 463-475.

5. Carvalho, L.H.M., De Koe, T., Tavares, P. B., 1998: An improved molybdenum blue method for simultaneous determination of inorganic phosphate and arsenate. Ecotoxicology and Environmental Restoration, 1, 13-19.

6. Cunniff, P. (Ed.), 1995: Official Methods of Analysis of Association of Official Analytical Chemists. 16th edn., AOAC International, Airlington, Va., USA.

7. Čapkovičová, A., Maková, Z., Piešová, E., Alves, A., Faix, Š., Faixová, Z., 2014: Evaluation of the effects of salvia officinalis essential oil on plasma biochemistry, gut mucus and quantity of acidic and neutral mucins in the chicken gut. Acta Veterinaria Beograd, 64, 138-148.

8. Daněk, P., Paseka, A., Smola, J., Ondráček, J., Bečková, R., Rozkot, M., 2005: Influence of lecithin emulsifier on the utilisation of nutrients and growth of piglets after weaning. Czech. J. Anim. Sci., 50, 459-465.

9. Durling, N.E., Catchpole, O. J., Grey, J. B., Webby, R.F., Mitchell, K. A., Yeap Foo, L., Perry, N.B., 2007: Extraction of phenolics and essential oil from dried sage (Salvia officinalis) using ethanol-water mixtures. Food Chemistry, 101, 1417-1424.

10. Emmert, J., Sartor, G., Sporer, F., Gummersbach, J., 2004: Determination of $\alpha$ - $/ \beta$-thujone and related terpemens in absinthe using solid phase extraction and gas chromatography. Dtsch. Lebensm. Rundsch., 100, 352-356.

11. Faixová, Z., Piešová, E., Maková, Z., Piešová, E., Takáčová, J., Cobanová, K. et al., 2009: Effects of borneol on blood chemistry changes in chickens. Acta Veterinaria, 59, 177-184

12. Farhat, G. N., Affara, N.I., Galli-Muhtasib, H. U., 2001: Seasonal changes in the composition of the essential oil extract of East Mediterranean sage (Salvia libanotica) and its toxicity in mice. Toxicon., 39, 1601/1605.

13. Golestani, M.R., Rad, M., Bassami, M., Afkhami-Goli, A., 2015: Analysis and evaluation of antibacterial effects of new herbal formulas, AP-001 and AP-002, against Escherichia coli O157:H7. Life Sci., 135, 22-26.

14. Gugliemo C. G., Karasov W.H., 1993: Endogenous mass and energy losses in ruffed grouse. The Auk, 110, 386-390. 
15. Hernández, F., Madrid, J., Garcia, V., Orengo, J., Megias, M.D., 2004: Influence of two plant extracts on broilers performance, digestibility, and digestive organ size. Poult. Sci., $83,169-174$.

16. Jakubas, W. J., Gulgielmo, C.G., Karasov, W.H., 1995: Dilution and detoxication costs: Relevance to avian herbivore food selection. In Proceedings of the USDA National Wildlife Research Center Repellents Conference, Lincoln, University of Nebraska, USA, 53-70.

17. Karasov, W.H., 1990: Digestion in birds: chemical and physiological determinants and ecological implications. Avian Biol., 13, 391-415.

18. Kirchgessner, M., Roth, F. X., 1983: Equation for prediction of the energy value in mixed feeds for pigs. J. Anim. Physiol. Anim. Nutr., 50, 270-275.

19. Kjeldahl, J., 1883: Neue Methode zur Bestimmung des Stickstoffs in organischen Körpern (New method for the determination of nitrogen in organic substances). Zeitschrift für Analytische Chemie, 22, 366-383.

20. Lakušić, B. S., Ristić, M. S., Slavkovska, V.N., Stojanović, D. L. J., Lakušić, D. V., 2013: Variations in essential oil yields and compositions of Salvia officinalis (Lamiaceae) at different developmental stages. Botanica Serbica, 37, 127-140.

21. Lever, M., 1977: Carbohydrate determination with 4-hydroxybenzoic acid hydrazide (PAHBAH): Effect of bismuth on the reaction. Anal. Biochem., 81, 21-27.

22. Marcin, A., Lauková, A., Mati, R., 2006: Comparison of the effects of Enterococcus faecium and aromatic oils from sage and oregano on growth performance and diarrhoeal diseases of weaned pigs. Biologia (Bratislava), 61, 789-795.

23. Mekinić, L.G., Skroza, D., Ljubenkov, I., Šimat, V., Možina, S. ̌., Katalinić, V., 2014: In vitro antioxidant and antibacterial activity of Lamiaceae phenol extracts: A correlation study. Food Technology and Biotechnology, 52, 119-127.

24. Puvača, N., Stanećev, V., Glamočič., D., Lević, J., Perić, L., Stanaćev, V., Milić, D., 2013: Beneficial effects of phytoadditives in broiler nutrition. World's Poultry Science Journal, 69, 1, $27-34$.

25. Regulation 1831/2003 EC on additives for use in animal nutrition, replacing Directive 70/524 EEC on additives in feedingstuffs [online], 2003. (http://europa.eu/rapid/press-release_IP-051687_en.htm) [cit. 2015-07-28]
26. Rideau, N., Nitzan, Z., Mongin, P., 1983: Activities of amylase, trypsin and lipase in the pancreas and small intestine of the laying hen during egg formation. British Poultry Science, $24,1-9$.

27. Santurio, D. F., da Costa, M. M., Maboni, G., Cavalheiro, C. P., de Sá, M. F., Pozzo, M. D. et al., 2011: Antimicrobial activity of spice essential oils against Escherichia coli strains isolated from poultry and cattle. Ciencia Rural, 41, 1051-1056.

28. Sibbald, I.R., 1982: Measurement of bioavailable energy in poultry feeding stuffs: a review. Can. J. Anim. Sci., 62, 983-1048.

29. Šarić, L., Čabarkapa, I., Šarić, B., Plavšić, D., Lević, J., Pavkov, S., Kokić, B., 2014: Composition and antimicrobial: Activity of some essential oils from Serbia. Agro Food Industry HiTech., 25, 40-43.

30. Traesel, C.K., dos Anios Lopes, S.T., Wolkmer, P., Schmidt, C., Santurio, J. M., Alves, S. H., 2011a: Essential oils as substitutes for antibiotic growth promoters in broilers: Seroproteins profile and lipid peroxidation. Ciencia Rural, 41, 278-284.

31. Traesel, C.K., Wolkmer, P., Schmidt, C., Silva, C.B., Paim, F. C., Rosa, A.P. et al., 2011b: Serum biochemical profile and performance of broiler chickens fed diets containing essential oils and pepper. Comparative Clinical Pathology, 20, 453-460.

32. van Loon, J. C., 1980: Analytical Atomic Absorption Spectroscopy, Selected methods. Academic press, New York, 337 pp.

33. van Soest, P.J., Robertson, J.B., Lewis, B.A., 1991: Methods for dietary fiber, neutral detergent fibre, and nonstarch polysaccharides in relation to animal nutrition. J. Dairy Sci., 74, 3583-3597.

34. Wallace, R. J., McEwan, N.R., McIntosh, F.M., Teferedegne, B., Newbold, C. J., 2002: Natural products as manipulators of rumen fermentation. Asian Australas. J. Anim. Sci., 15, 1458-1468.

35. Westendarp, H., 2005: Essential oils for the nutrition of poultry, swine and ruminants. Deutsche Tierärztliche Wochenschrifte, 112, 375-380.

36. Windisch, W., Schedle, K., Plitzner, C., Kroismayr, A., 2007: Use of phytogenic products as feed additives for swine and poultry. J. Anim. Sci., 86, Suppl. 9, E 140-148.

37. Zheljazkov, V.D., Astatkie, T., Shiwakoti, S., Poudyal, S., Horgan, T., Kovatcheva, N., Dobreva, A., 2014: Essential oil yield and composition of garden sage as a function of different steam distillation times. Hort. Sci., 49, 785-790. 